\title{
PEDAGOGIŲ NERIMO SUTRIKIMUS IR DEPRESIŠKUMĄ SKATINANČIŲ VEIKSNIŲ ANALIZĖ IR PSICHOEDUKACIJOS GALIMYBĖS
}

\author{
Jūratė Sučylaitė \\ Klaipédos universitetas, Respublikiné Klaipédos ligoniné
}

Raktažodžiai: depresija, kūrybiški metodai, nerimo sutrikimai, pedagogai, psichoedukacija.

\begin{abstract}
Santrauka
Straipsnyje analizuojama, kokie psichologiniai ir sociokultūriniai veiksniai skatina nerimo sutrikimus, didina depresiškumą, kokiais psichoedukacijos metodais galima sumažinti jų veikimą. Atliktas kokybinis tyrimas. Ištirta dešimt Psichiatrijos departamente gydytų 48-54 metų pedagogių, sergančių nerimo sutrikimais ar depresijos epizodu, pusantro ménesio dalyvavusių psichoedukacineje programoje. Psichoedukacinè programa apėmè ne tik žinių apie psichikos sveikatos sutrikimus teikimą, bet ir bendravimą savitarpio pagalbos grupeje, poetikos terapijos metodu naudojimą dialogo spontaniškumui padidinti ir unikalių išgyvenimų raiškai palengvinti. Visi tiriamujų pasisakymai psichoedukacinių susitikimų metu buvo užrašyti, duomenys analizuoti, vadovaujantis fenomenologiniu ir hermeneutiniu-interpretaciniu požiūriais. Rezultatai parodè, kad tiriamosios dažnai patiria stresą, yra linkusios ignoruoti neigiamus išgyvenimus ir jų nepripažinti, todèl turi sunkumų suvokdamos savo pačių psichikos būseną ir asmeninę poziciją realiose gyvenimo situacijose. Spontaniškai prasidejęs pokalbis apie pedagoginę praktiką dažnai sustiprindavo nemalonias somatines reakcijas: kūno drebėjimą, veido raudimą, ašarojimą, kalbos užsikirtimus. Programos metu ị tiriamujų psichikos sutrikimus pažvelgta kaip į individualias gyvenimiškąsias krizes. Bendravimo su pacientemis metu kūrybiškai vystytas dialogas, teikta emocinė parama, išryškinti galimi egzistenciniai pasirinkimai. Po 6 psichoedukacinių susitikimų visos tiriamosios pažymėjo, kad pradejo labiau pasitikèti savimi, atsirado vilties, pradejo lengviau kalbèti apie savo gyvenimą, sumažejo kūno drebejjimo priepuolių, pajaute kūrybišką ịkvèpimą, galimybė dalintis dvasiniais išgyvenimais su kitais suteikè džiaugsmo, gavo reikalingų žinių. Pa-
\end{abstract}

darytos išvados: psichoedukacija yra efektinga, kai ji kompleksiškai apima bendravimą savitarpio pagalbos grupejje, kūrybiškos raiškos metodus ir žinių apie ligą teikimą ir gali būti integruojama ị gydymo programas. Atlikus tyrimą galvojama, kad savojo identiteto suvokimo sutrikimų būtų mažiau, jei daugiau būtų skatinama pedagogų refleksinè praktika, jei analizuojant asmeninę patirtị daugiau dèmesio būtų skiriama meniniams kūrybiškiems metodams, padedantiems išreikšti autentiškas emocijas, jei būtų mokomasi ne ignoruoti savo jausmus, o juos suvokti ir pažinti, suprasti jų vietą asmeniniame gyvenime ir profesineje veikloje. Daroma prielaida, kad susietas su emocijomis, kūrybiškas, refleksinis mokymasis suvokti savo identitetą leistų pedagogams išsaugoti geresnę savivertę, padètų išvengti depresiškumo simptomų pasireiškimo ir suvaldyti nerimą bei atliktų psichikos sveikatos sutrikimų prevencijos funkciją.

\section{Ivadas}

Pastaruoju metu dažnai diskutuojama apie profesinio „perdegimo“ sindromą, kuris suvokiamas kaip socialinėje sferoje dirbančių žmonių psichinis ir fizinis išsekimas. Maslach ir Jackson (1984), kalbedami apie ,perdegimo“" sindromą, akcentavo emocinị išsekimą, depersonalizaciją (savojo identiteto suvokimo sutrikimą), asmeninio pajègumo sumažejimą [1]. Koekkoek, van Meijel, Schene, Hutschemaekers teigia, kad nesėkmingai gydomų lètinèmis depresijomis sergančių pacientų slauga profesionalams gali sukelti beviltiškumo ir bejejgiškumo jausmus, demoralizuoti ir tuo pačiu pakenkti gydymo sékmei. Taip pat pastebèta, kad pacientu įtraukimas ị reabilitacijos programas, jų socialinių problemų sprendimas daro teigiamą poveiki personalui, be to, pastebėta, kad siekimas suprasti depresijos reiškinį, integruojant i visumą visas farmakologines ir psichoterapijos žinias, mokymasis pažinti paciento - profesionalo sąveikos poveikį specialisto psichikai saugo nuo demoralizacijos [2]. Pedagogikos kontekste ir pedagogų sveikatos tyrimo kontekste stokojama tyrimų, îrodančių, kokį poveiki pedagoginis sąveikavimas 
su mokiniais daro mokytojų depresiškumui (beviltiškumui, bejègiškumui, energijos stokai ir kt), kaip mokinių socializacijos sẻkmingumas veikia mokytojo savivertę ir moralumą. Žinoma, kad neigiami vidiniai išgyvenimai visiems yra sunkūs, kad žmonès nesąmoningai vengia juos išgyventi ir pripažinti jas savo paties dalimi, bet emocijų nepripažinimas, vengimas jas išgyventi skatina asmenị vadovautis taisyklèmis, kurios neleidžia suprasti tikrujų savo minčių ir emocijų [3]. Dėmesio sutelkimo ị emocijas ir dvasingumą prasmè vis dažniau akcentuojama suaugusiujų transformuojančiojo mokymosi kontekste [4]. Rengiantis tyrimui dareme prielaidą, kad, analizuojant konkrečių gyvenimo situacijų prasmes, mokymasis išgyventi emocijas ir jas pažinti padidins depresija ar nerimo sutrikimais sergančių pedagogių savo identiteto suvokimą, sutelks vilties ir palengvins gydymo procesą. Taip pat daryta prielaida, kad kokybinio tyrimo įžvalgas bus galima perkelti ị psichikos sutrikimų prevencijos kontekstą ir patikrinti kiekybiniu tyrimu.

Darbo tikslas - išsiaiškinti veiksnius, sudarančius prielaidas depresija ar nerimo sutrikimais sergančių pedagogiu depresiškumui ir nerimo simptomams pasireikšti bei parodyti psichoedukacijos galimybes.

\section{Darbo metodika}

Atliktas kokybinis tyrimas. Tyrimas vyko Psichiatrijos departamento Psichosomatiniu sutrikimų skyriuje pusantro menesio. Iš viso tyrime dalyvavo 10 depresija ir nerimo sutrikimais sergančių pedagogių: 5 dalyvavo pirmojoje trijų savaičiu programoje, likusios 5 antrojoje. Programos buvo identiškos. Susitikta du kartus per savaitę, susitikimo metu dirbta po 90 minučių. Vienoje ir kitoje grupeje ivvyko 6 susitikimai, kurių metu skaityta nuo vieno iki trijų Justino Marcinkevičiaus, Vinco Mykolaičio - Putino ar Henriko Nagio eilèraščių. Perskaičius eilèraštic, klausta, kokią nuotaiką sukèlè tekstas, gal sužadino prisiminimus. Dėmesys buvo sutelktas ị literatūros kūrinio temos, atskiru simboliu siejimą su asmenine patirtimi ( prašyta papasakoti apie konkretų vakarą, medị, upę ir t.t; apie konkrečius jausmus ir mintis, išgyventus tą konkretų vakarą, prie konkrečios upès, medžio ir t.t). Leista tolti nuo eilèraščio temos, telkti dèmesị i tai, kas tiriamajai yra prasminga, rūpi čia ir dabar. Ignoruoti abstraktūs, su subjektyvia patirtimi nesiejami apmąstymai. I kylančius klausimus atsakyta, suteikiant tiriamosioms aktualių žinių. Pokalbio metu buvo duodama kūrybiškų užduočių. Pavyzdžiui, iš akmenukų sudèstyti ateitị simbolizuojančią mozaiką ir paaiškinti jos prasmę, savo dabartinę poziciją išreikšti metafora (Aš kaip upé, žuveddra ir t.t., plaukiu, skrendu ir t.t.) Susitikimo metu skatintas bendruomeniškumas (tarpusavio pagalbos grupès kūrimasis), teiktos žinios (egzistencinès ir žinios apie ligą), naudoti poetikos terapijos metodai (poetinè improvizacija, poetiniai palyginimai ir t.t [5]. Visos tiriamujų mintys, išsakytos susitikimų metu, užrašytos ir interpretuotos, vadovaujantis fenomenologiniu ir hermeneutiniu - interpretaciniu požiūriais.

\section{Tyrimo rezultatai ir jų aptarimas}

Pokalbis, sužadinantis mokyklos ir pedagoginio darbo prisiminimus, tiriamosioms sukeldavo bejègiškumo išgyvenimą, kuris visais atvejais siejosi subjektyviu nuovargio jautimu.5 informantès išreiškè tikejjimą, kad „nuovargio jautimas yra laikinas dalykas", yra nulemtas psichikos funkcijų „laikino pablogejimo“, ir jau dabar ,galima matyti, kad sveikata taisosi, daugèja energijos". Kitais atvejais kalbejimasis apie pedagoginę patirtį buvo susietas su ryškiu somatinès būsenos blogejjimu: pastebètas veido raudimas, ašarojimas, burnos džiūvimas, poreikis išgerti vandens, kad galètų tęsti pasakojimą (3 atvejai), stiprus viso kūno tremoras, veido grimasos, atsirandančios nepajėgiant ištarti norimo žodžio (2 atvejai).

Pastebėta, kad visos tiriamosios dabartic sieja tik su darbingumo praradimu, nuovargiu, neišnykstančiais ligos simptomais, o praeiti - su profesiniu sẻkmingumu, pripažinimu, atsidavimu savo darbui. Ligos pasireiškimo priežastis, tiriamujų nuomone, buvo per didelis noras padèti kitiems, dažnas aukojimasis. Tiriamosios, kurioms pokalbis apie profesinę veiklą sukeldavo mažiau išryškejjusias somatines reakcijas arba iš viso jų nesukeldavo, buvo linkusios kalbèti ne tik apie prarastą darbingumą ir ligos paūmèjimą, bet ir apie kūrybišką saviraišką, pomègius, taip pat apie per dešimtmetį sukauptą depresijos epizodų íveikimo patirti ir daug psichikos jègu pareikalavusias pastarojo laiko traumas, dažniausiai, apie šeimos narių netektis. Tiriamosios, kurioms buvo ypač sunku kalbèti apie darbą mokykloje ir kurioms pokalbis sukeldavo ypač ryškias somatines reakcijas, tvirtino, kad savų jègų netausojimas darant kitiems gera, didelis sąžiningumas, darbas be poilsio lèmè jų organizmo susidèvejjimą, negrižtamą psichikos jègų išsieikvojimą. Jos skaudžiai išgyveno, kad dabartyje esančios visiškai bejejgès, ir kad tas bejejgiškumas per keletą savaičių nemažeja; tvirtino, kad šeimos nariai jas supranta ir palaiko, atostogų metu joms yra galimybiu pakeliauti, kartais nueinančios ị koncertą, teatrą, bet pokalbio metu asmeninès patirties prasmes jos atskleisdavo lakoniškai, dalykiškai, racionaliai, nepavyko pastebèti autentiškumo: nuostabos reaguojant ị vieną ar kitą poetinį vaizdą, susižavejjimo ar piktinimosi kalbant apie vieną ar kitą gyvenimo reiškinį, konkrečioje vietoje konkrečiu laiku išgyvenamą individualų jausmą nusakančių detalių. Buvo įžvelgta, kad savęs paties (identiteto) suvokimas yra blogesnis tais atvejais, kai pokalbio apie pedagogo darbą metu pasireikšdavo ryškesnès somatinès reakcijos. İžvelgta, 
kad yra ryšys tarp gebejjimo suvokti save pačią ir gebejjimo autentiškai reaguoti i aplinką bei autentiškai kalbèti. Kai mažèja aplinkos įspūdžių, kai siaurèja emocijų spektras, blogejja savojo identiteto suvokimas.

Analizuojant tiriamujų požiūrị i save pačią, išryškèjo dvi tendencijos. Vienoms būdingas ypač didelis polinkis analizuoti save, kitoms - baimè pažinti savo vidini pasauli. Nuolat save analizuojančios pacientès mokèjo suprasti ir ivardinti turimas charakterio savybes, asmenines vertybes, gebejo ịvardinti traumavusius veiksnius, turejusius neigiamos įtakos jų asmenybės raidai, bet joms labai sunkiai sekèsi pasinaudoti turimomis savęs tyrinèjimo ir bendrosiomis psichologijos žiniomis kuriant tolesnio gyvenimo viziją, nesisekè pozityviai keisti požiūrị ị save pačią, ị savo galimybes. Visos turimos psichologijos žinios dažnai būdavo pritaikomos neigiamų, beveik fatališkų asmeninių nuostatų patvirtinimui: „Aš esu perdaug jautri, todèl negaliu ilgiau bendrauti su žmonèmis“, „, Aš perdaug pedantiška, aš turiu viską padaryti tobulai, o tam nèra laiko, dèlto graužiuosi, blogèja sveikata, bet kitokia aš jau nebūsiu“. İžvelgta, kad negebejimas vadovautis turimomis psichologijos žiniomis yra susietas su neigiamomis emocijomis, kurių viso gyvenimo eigoje nesąmoningai buvo stengiamasi išvengti ir kurios reikšmingos vidinių barjerų atsiradimui.

Kitos tiriamosios venge patyrinèti save pačią: „Kiti geriau žino, kokia aš esu“, „Man sunku charakterizuoti save, galiu būti neobjektyvi“. Ir save analizuojančioms, ir vengiančioms save pažinti tiriamosioms reikèjo emocinès paramos, patvirtinimo, kad jos yra pajègios pažinti savo gyvenimą, imtis atsakomybès už jị ir mokytis įveikti sunkumus. Visoms tiriamosioms buvo būdinga baimé autentiškai gyventi, baimè suklysti ir tikèti, kad suklydus užteks jègų ištaisyti klaidą. İžvelgtas ryšys baimès suklysti ir didesnių dvasinių tikslų stokos ryšys.

Kelios tiriamosios prisipažino, kad pablogèjus sveikatai, kitaip pradèjo galvoti apie probleminio elgesio mokinius, jauté jiems užuojautą: , Gal viduje jiems labai blogai. Gal dar blogiau negu man, gal jų niekas nesupranta" ir situacijos beviltiškumą: „Bet ką gali padaryti, kai jie tranko duris ir visus siunčia ant trijų raidžių? Būna, kartais pavyksta, kai daugiau žinai apie jų gyvenimą“، İžvelgème, kad suvokta asmeniné kančia didina jautrumą kitų kančioms ir gebejjimą pamatyti užmaskuotą žmogaus kančią, besislepiančią po keisčiausiu elgesiu. Tiriamosios pripažino, kad jos esančios kitokios negu dauguma žmonių, pastebinčios daugiau problemų socialiniame gyvenime, jautriau reaguojančios ir todèl joms sunku prisitaikyti visuomenejje.

Didžioji dauguma tiriamųjų dabartyje nemate gyvenimo prasmès, nežinojo jame savo vietos, buvo įsitikinusios, kad jos nebegalèsiančios dirbti pedagoginio darbo, antra vertus, jos neslëpè, jog dažnai jautė pasitenkinimą, kai jų rengtas moksleivis laimėdavo konkursą ar olimpiadą, kai pavykdavo gerai suorganizuoti renginị. Racionalūs apmąstymai jas skatino trauktis iš pedagoginio darbo, o emocinis santykis su profesine veikla buvęs prieštaringas. Tiriamosios prisipažino, kad skaudina visuomenès požiūris ị mokytojus kaip ị Žemos kvalifikacijos specialistus, nesugebančius suprasti, išmokyti ir išauklèti vaikų, kaip į žmones, neturinčius galimybių daugiau uždirbti. Neigiamus išgyvenimus joms kèlè mokykloms vadovaujančių institucijų didejjantys reikalavimai, taip pat moksleivių ciniškas juokas mėginant kalbèti dvasingumo, žmogaus būties, gyvybès ir mirties temomis. Nepaisant visų neigiamų emocinių išgyvenimų, neatsiejamų nuo pedagoginès patirties, nemaža dalis tiriamuju prisipažino, kad daugiausia teigiamų emocijų jos išgyveno darbe ir nori dirbti mokytojos darbą. Ne viena tiriamujų sutiko, kad turi sukaupusios daug unikalios profesinès patirties ir būtu ịdomu ją analizuoti, apibendrinti, bet nesvajojo savo profesinę patirti apibendrinti atskirame leidinyje ar straipsnyje ir ji viešai pristatyti, jautèsi nenusipelniusios pasidalinti geraja patirtimi su kitais specialistais, nepaisant to, kad buvo pripažintos kaip labai geros savo dalyko specialistės. İžvelgta žemos savivertès problema.

Tiriamosios, kurioms diagnozuoti nerimo sutrikimai ir yra pasireiškę nerimo atakų, charakterizuoja savo asmenybę labai neigiamai arba labai teigiamai, ịžvelgdamos savyje tik labai stipriai asmenybei būdingas savybes. Dauguma jų ignoruoja savo nuovargi, apmaudą, apimantị, kai nepasiseka ar susiduriama su neteisybėmis, liūdesị, stengiasi šių jausmų nepastebèti ir neišgyventi, tai tampa emocinès įtampos priežastimi, pažeidžia asmenybès vientisumą.

Fenomenologiškai analizuojant pedagogių, hospitalizuotu pasireiškus depresijos epizodui ar esant nerimo sutrikimams, gyvenimiškąsias situacijas, jose galima įžvelgti krizę, kuriai būdingas: 1) sunkus savęs pačios (identiteto) suvokimas, susijęs su profesinio vaidmens atlikimu; 2) priklausomybè nuo kitų požiūrio, neleidžianti vadovautis savo jausmais, patirtimi ir supratimu charakterizuojant savosios asmenybès savybes; 3) nelankstus, neemocingas pasakojimas apie atskirus gyvenimo epizodus, vengiant atskleisti subjektyvias prasmes, atrastas ar patvirtintas konkrečioje aplinkoje konkrečiu laiku; 4) asmeninès pozicijos netekimas, susietas su gyvenimo prasmès nematymu, konfliktu vertybių pasaulyje (vertybės, kuriomis tikèta, tebeaktualios, bet kiti žmonès joms abejingi).

Po 6 psichoterapinių susitikimų, visos tiriamosios pažymejjo, kad pradejo labiau pasitikèti savimi, atsirado vilties, pradèjo lengviau kalbèti apie savo gyvenimą, sumažèjo kūno drebejjimo priepuolių, pajautė kūrybišką įkvėpimą, turèjo galimybę dalintis dvasiniais išgyvenimais, gavo reikalingu 
žinių. Visos tiriamosios pažymėjo, kad psichoterapiniai pokalbiai labai reikalingi, dalis tiriamujų teigè, kad psichoterapija efektyvesnè už medikamentini gydymą, dalis tiriamujų vienodai vertino psichoterapijos ir medikamentų poveiki ir pageidavo būti gydomos kompleksiškai.

Tikètina, kad šiuos edukacinius - kūrybiškus metodus taikant praktiškai sveikų pedagogų grupelèse galima būtų išugdyti pedagogų refleksinio mąstymo, savęs pažinimo kompetencijas ir tokiu būdu atlikti nerimo suvaldymo sutrikimų ir depresiškumo pasireiškimo prevenciją.

\section{Išvados}

1. Somatiniai nerimo sutrikimai ryškesni, kai asmens savo identiteto suvokimas yra blogesnis, yra sumažejęs atvirumas aplinkos ịspūdžiams ir susiaurejęs išgyvenamų emocijų spektras.

2. Profesinè veikla sukelia neigiamų emocijų, bet nesąmoningai stengiantis išvengti jų išgyvenimo, daugèja vidinių barjerų ir mažeja saviverte, dèl to nebekeliami aukštesni tikslai, silpnėja asmeninè pozicija ir mažèja gyvenimo prasmès jausmas.

3. Psichoedukacija tarpusavio pagalbos grupèse, papildyta kūrybiškos raiškos metodais, mažina nerimo sutrikimų somatinių simptomų skaičių, lengvina depresija ir nerimo sutrikimais sergančiųų verbalinị ir socialinị bendravimą, suteikia vilties.

\section{Literatūra}

1. Insaf Altun. Bournout and nurses' personal and professional values. Nursing Ehics 2002; 9(3), 270-278.

2. Koekkoek B, van Meijel, Schene A, Hutschemaekers G. Clinical problems in the long-term care of patients with chronic depression. Journal of Advanced Nursing 2008; 62(6), 689-697.

3. Coggins J, Fox J. Qualitative exploration of emotiona inhibition: a basic emotions and developmental perspective. Clinical Psychology and Psychotherapy 2009; 16, 55-76.

4. Dirkx J. Transformative learning and the journey of individuation. ERIC 2000.

5. Sučylaitė J., Švedienė L. Poetikos terapijos metodas reabilitacijoje 2011, Klaipèda

THE ANALYSIS OF FACTORS ABLE TO STRENGTHEN TEACHERS' ANXIETY DISORDERS AND SYMPTOMS OF DEPRESSION, AND THE BENEFIT OF PSYCHOEDUCATION

\section{J. Sučylaitė}

Key words: teachers, anxiety dissorders , depression psychoeducation, creative methods.
Summary

Objective. To evaluate factors able to strengthen symptoms of the anxiety disorders and depression and to show possibilities of psychoeducation

Methods. Qualitative research.10 women ill with anxiety disorders or depression were involved into the psychoeducation program. Two groups were organized in Psychiatric department. Each group had 6 meeting during 3 weeks. Having purpose to disclose patients' personal meanings poetry reading was used in every group. Poetry served as a source of free associations and helped to develop dialog on various topics important for group members. Existential knowledge and information of the disease mechanism were given during group discussion. Creative artistic methods were used with purpose to express emotions and thoughts in more authentic way. All thoughts were written down and analyzed in phenomenological and hermeneutic- interpretative way.

Results. Somatic symptoms were more stronger when perception of self identity was lower. Somatic symptoms became stronger when conversation reached question of professional experience. By words of the informants "strong will to do good works and many efforts put to help other people" brought to weakness and exhaustion of psychic energy. A lack of external world impressions and smaller palette of emotions were noticed when the perception of self identity was smaller. Some informants were afraid to understand inner experiences and to disclose qualities of own personality, other had difficulties trying to apply psychological knowledge into management of personal life. They used psychological knowledge to defend their rules associated with their emotional limits. Other had a fear to be wrong trying to disclose qualities of their personality, and disclosed only negative qualities only or only positive. They confessed that they try to ignore negative emotions and weakness. Rationally they wanted to leave pedagogical practice, but emotional ambiguity was noticed. Low self evaluation blocked will to share the best professional practice with other and lead to low self evaluation, lack of spiritual goals and life meaning. The program improved their ability to communicate in the group, to express inner experiences verbally, give a hope.

Conclusion. Somatic symptoms in case of anxiety disorder are stronger when perception of self identity is smaller; when is a lack of openness to impressions of external world and smaller variety of emotions. Professional work gives negative emotions, but trying to escape an experience of these emotions lead to lower self evaluation, spiritual goals disappear and life meaning is lost. Psychoeducation reached with creative artistic methods helps to reduce somatic symptoms in case of anxiety disorders, and to reduce symptoms of depression in case of depression or anxiety disorder; bring hope, promotes the skills of verbal and social communication

Correspondence to: sucylaite@gmail.com

Gauta 2012-09-14 